\title{
The Great Gray Owl of the Woodlands
}

\section{By Clifford Law, Choiceland}

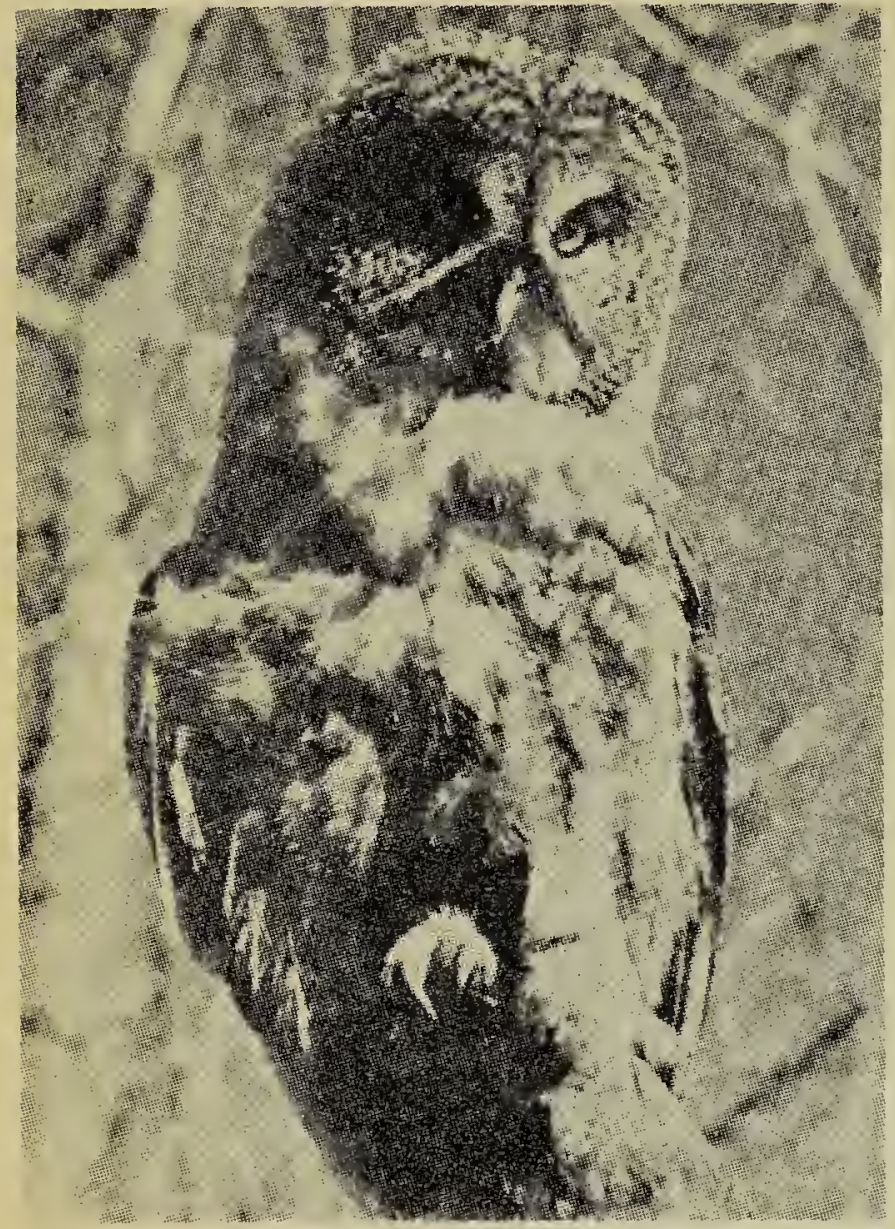

Photo by A. F. Oeming GREAT GRAY OWL

In the last twelve years, in the mild weather of early winter between November 15 and December 20, I have seen no less than 15 Great Gray Owls. Usually I see just one each fall, but lasit fall (1959) four of these owls were seen around the buildings and sitting in trees along the edges of the grain fields. As the cold, windy weather sets in, the owls move away to more sheltered places.

My farm is located along the north boundary of Fort a la Corne Grame Reserve, eight miles southwest of the town of Choiceland. The Fort a la Corne Game Reserve has dense bluffs of spruce, poplar, pine and tamarack with many open meadows, making an ideal place for the Great Gray Ow! to spend the winter months-well sheltered, and with an abundance of meadow mice.
Few people have ever seen the Great Gray Owl and perhaps some who have seen it have mistaken it for the Great Horned Owl which is similar in size. As most people are familiar with the Great Horned Owl a comparison of the two species may be helpful. I want to describe the noble and beneficial Great Gray Owl as completely as possible so that everyone can recognize and help to protect it.

In appearance the Great Gray is a very large owl, larger than the Great Horned. The writer once measured a specimen taken for a museum; the wing span was 47 inches and the length of the owl 23 inches. The appearance, however, is rather deceiving for the owl looks big chiefly because of its very bulky feathers, its weight being no greater than a Great Horned Owl.

The two sexes are different in size and colour-one being larger and darker, and the other (presumably the male) being smaller and lighter in colour. These smaller birds are about the same size as a full-grown Great Horned Owl.

The most conspicuous features of the Great Gray Owl are its large round head and its very dark feathers. The widith of the owl's head would be between five and six inches across the face, and the neck is even wider-perhaps eight inches at the base. Because of the thick head feathers, the face looks flat and sunken. Unlike the Great Horned Owl, the Great Gray Owl has no feathered tufts on the top of its head. This is the easiest way to distinguish these two large owls. The feathers on the owl's back are very dark grey from the head to the wings, becoming a brownish grey from the base of the wings to the tail, and a lighter brown and grey on the tail itself.

Again on the front, the feathers are very dark grey (almost black) down to the breast. Below the beak there is a band of pure white feathers about three-quarters of an inch wide across the owl's face, looking at a distance like a white moustache. This 
strip of white is narrower and shorter in some birds (perhaps the females?). From the breast to the legs, the feathers are steel grey. Two streaks of brown, about two inches apart, run down the breast to the legs. The underside of the tail is light browngrey. The feathers on the legs are fine, close and greyish brown. The feathers on the toes and between the toes are also short and dense, but dark grey in colour. The toes are rather short, with curved needlesharp talons for hunting its prey.

The Great Gray Owl flies quite slowly. When it is flapping its wings, the wing flaps are much like a Sandhill Crane's, or a wild goose's, but it does about eighty per cent of its flying by just gliding. The Great Horned Owl flies with rather fast, jerky flapping of the wings.

Another great difference between the two owls is in the way they perch in the trees. As dusk approaches the Great Horned Owl flies out of the dense timber and perches on the top of a high tree or tall stump near a field in stubble or swath. From this position it can quite easily see its next victim-be it rabibit, mouse, red squirrel, rat or bird-all of which are on its menu.

The Great Gray Owl's manner of perching is almost the very opposite. It rarely flies to the top of a high tree, but selects a side limb of a fairsized poplar or spruce eight to twelve feet from the ground. From there it sails out to the stubble or swathed grain field to catch a mouse.

The Great Gray Owl's hearing is very acute. For this reason, its method of hunting differs from that of the Great Horned Owl. Ninety-five per cent of the time, the Great Horned Owl gets its food by seeing its victims, whereas the Great Gray Owl locates its food by hearing only. At least, it seems to depend on hearing in the early winter when eight to twelve inches of soft snow covers the grain fields and meadows. As the Great Gray Owl sits, slowly turning its head from side to side and sometimes looking straight down below it, we learn to know that it is picking up the sound of a mouse chewing up straw or grain. Silently it sails off its perch to a distance of about sixty yards, hovers over a spot for a few minutes and then drops suddenly down into the soft snow. After remaining motionless for a couple of minutes, it slowly raises one foot out of the snow with a dead mouse in its talons. The owl then proceeds to swallow the mouse whole, and after that it flies back to its perch or to ancther tree limb nearby. This performance may go on for hours, as at least two-thirds of the owl's victims escape for various reasons such as deep snow, a protecting straw or chaff cover over the mouse, or the frozen crust of snow. The owl keeps on hunting until it catches enough mice to satisfy its hunger for several hours perhaps eight or ten miceand then flies a few rods into deeper timber where it will doze for several hours in a fair-sized tree.

The Great Gray Owl's diet seems to consist wholly of mice. On several occasions I have seen chickadees and juncos in the same tree only a few feet away from the owl but making no commotion. They merely seemed curious about the owl. The owl, for its part, didn't pay the slightest attention to these small birds. I have also seen Blue Jays in the same tree which showed no signs of fear of the owl, and the owl made no move to attack them. On another occasion I saw nine Ruffed Grouse eating at an oat stack with a Great Gray Owl perched twelve feet up in a poplar not more than four rods away. The grouse watched the owl from time to time, but showed no alarm, and the owl didn't pay the least attention to the grouse. After very close observation of the Great Gray Owl, the writer feels that this owl does not prey on birds, and that it can be rated as one hundred per cent beneficial to the farmers.

Great Gray Owls show very little fear of man, and it is quite easy to walk up to a tree they are sitting in. Apart from man, these owls have few enemies. I have seen a Goshawk on several occasions making dives at one, but the owl merely ruffled its feathers and ducked its head, until the Goshawk moved on. Ravens have been seen flying with the owl, but never diving at it.

In the first week of May, 1949, I found a Great Gray Owl's nest in the Fort à la Corne Game Reserve. The owl had used a vacated hawk's nest 
about twenty-six inches across built at the base of three large limbs and against the tree trunk about twenty feet up in an Aspen Poplar which would measure about fourteen inches at the base. One Great Gray Owl was sitting on the nest, and the mate on a limb close by. When I was about twenty yards from the tree with the nest, the owl sitting on the limb lowered its wings, ruffled its feathers and started to snap its beak. The owl on the nest did not leave. There was no way to climb the tree to see whether there were eggs or young. Since spring work had started on the land, I did not get back to visit the nest again.

The nest tree was located in a small poplar bluff with trees of varying sizes, surrounded by a thick stand of spruce. The poplar and spruce together covered five acres, an area surrounded on three sides by open meadows. The protection offered by the bluff, and the plentiful supply of mice in the meadows nearby, made this an ideal nesting site.

All my observations of the Great Gray Owl prompt me to say, to farmers in particular, and to all wildlife lovers and big game hunters-do not kill this owl; it should be fully protected.

\section{FURTHER REPORTS OF GREAT GRAY OWLS}

\section{By Maurice G. Street, Nipawin}

With a number of reports of Great Great Owls coming in this year, I believe you will be interested in the following. In November (1959) Miss Ann Matthews of Nipawin saw four Great Gray Owls in a distance of one mile while driving north of the $C$. Stuart Francis farm at Torch River. They were all seen sitting on tree stumps quite close to the road. Also in November, Walter and Billy Matthews came upon a Great Gray caught in a trapper's mink-set, while hunting along the Torch River. This bird was removed from the trap, one damaged leg was amputated, and the bird was then released in quite good condition. The Matthews also saw another Great Gray in December, in the same general region.
On November 20, 1939, I saw my first Great Gray Owl (in the wild state) 14 miles northeast of Nipawin. This one was also sitting on a tall tree stuo overlooking an unharvested grain field. The time was late afternoon. Then on December 17, shortly after dark, one sat for a time on my television antenna which is 65 feet above ground level. I saw it quite clearly in the beam of my flashlight.

When I was speaking to Louis Aasen, a trapper in the Mossy River area, recently, he told me large owls were very abundant along the Mossy River north of the Torch River. These owls may have been Great Horned Owls or Great Grays, or both. Great Horned Owls are very scarce here about Nipawin and along the Torch. There are great numbers of the Snowshoe Rabbit throughout this entire region.

Editor's Note: Note also C. Stuart Francis' record of the Great Gray Owl at Spruce Dale Farm (Torch River, Sask.) on page 3 of this issue.

\section{CONTROL OF MAGPIES BY GREAT HORNED OWLS}

The role of the Great Horned Owl in controlling magpie populations is shown in a recent study of magpie ups and downs made in Montana by Dr. John Craighead, Leader of the Montana Co-operative Wildlife Research Unit (Robert L. Brown. Magpie ups and downs. Montana Fish and Game Dept. Info. Bull.\#3, not dated). The extent of predation by Great Horned Owls was studied by tethering young owls on the ground below their nests. Both adult birds continued to feed and protect their young; hence food remains and pellets could be examined to see what the young owls had been fed. In this way it was found that $\mathbf{5 7}$ magpies were included in the food items of eight young owls during three weeks of the nesting season (1956, 1957). Few people appreciate the role Great Horned Owls play in reducing annual magpie surpluses. [Ed.] 